\author{
Снежана М. МИЛОСАВљЕВИЋ МИЛИЋ ${ }^{*}$ \\ Универзитет у Нишу \\ Филозофски факултет
}

\title{
МОДЕЛИ РЕЦЕПТИВНОГ ОДГОВОРА У САВРЕМЕНОЈ СРПСКОЈ КЮИЖЕВНОСТИ ЗА ДЕЦУ
}

\begin{abstract}
Полазећи од методолошких претпоставки савремених теорија читања, у раду се анализирају модели читаоца у књижевности за децу, који су садржани у инстанцама имплицитног читаоца (V. Iser), наратера (G. Prince) и наративне публике (J. Phelan, P. Rabinowitz). Усмереност лирског или епског наратива ка детету као „идеалном реципијенту” и иманентној генеричкој ознаци, имплицитно отвара питање (не)усаглашености интепретативних стратегија. Тумачење рецептивних компетенција вишеструке и често амбивалентне фигуре читаоца може помоћи приликом објашњавања „херменеутичке сложености” многих дела књижевности за децу чији се фикционални светови развијају „на више нивоа сложености” који су „прилагођени различитим узрастима” реципијената (Шефер 2001: 249). Функционални опис рецептивних инстанци може представљати и базично полазиште за ревизију методолошко-интерпретативних аспеката овог књижевног жанра. Изворну литературу у истраживању примарно чине текстови савремених српских аутора књижевности за децу: Милована Витезовића и Рајка Петрова Нога.

Кључне речи: књижевност за децу, имплицитни читалац, наративна публика, наратер.
\end{abstract}

Интерес за рецепцију књижевног текста у науци о књижевности почиње се интензивирати 30-их година прошлог века, посебно унутар феноменолошки оријентисане књижевне теорије. Уводећи једну од првих типологија читалаца, Роман Ингарден указује на разлике између активног и пасивног читаоца. Док потоњи књижевно дело разуме на денотативној равни, активни читалац је учесник у креирању значења дела. Читати активно за Ингардена значи партиципирати у тексту, односно, прихватити улогу саучесника у откривању његовог смисла. У данас добро познатој Ингарденовој теорији о слојевитој структури текста посебно треба издвојити „слој схематизованих аспеката” као индикативан за улогу читаоца, будући да управо „места неодређености" која су неизбежан део света сваког фикционалног текста, траже конкретизацију, неку врсту опредмећености у чину читања.

\footnotetext{
*snezana.milosavljevic.milic@filfak.ni.ac.rs
} 
Оно што је у том процесу попуњавања празнина и места неодређености контролисано текстом, добиће своју терминолошку ознаку у радовима Ингарденовог настављача, Волфганга Изера, у данас опште прихваћеном теоријском појму имплицитни читалаи. Овај читалац, према Изеру, чиста је текстуална категорија, стратегија (најчешће наративна ${ }^{1}$ ), која усмерава правац исправног или адекватног читања. Отуд се његов метонимијски лик увек може свести на јединствени ентитет, као на фигуру која јемчи за кохерентност и интерпретативну целовитост рецепције.

Као концепт, имплицитни читалац је укорењен у самој структури текста; будући конструкт, ни на који начин се не може изједначити ни са једним реалним читаоцем (Изер 1978: 34).

Усмерена, не толико на реторичке аспекте пријема, колико на комуникативне потенцијале текста и интерактивну природу читања, Изерова теорија као да је превиђала случајеве комплекснијих, жанровски хетерогених текстова, који претпостављају неколико сличних или различитих имплицитних читалаца. Сучељеност или непомирљивост интерпретативних стратегија контролисаних текстом очито да је морала довести у питање методолошку апликативност Изеровог концепта. У постизеровској терминолошкој и методолошкој пролиферацији рецепцијских инстанци, осим унутар покрета критике читалачког одговора (Reader's Response Criticism), типологија рецепцијских фигура допуњена је 70-их година прошлог века Принсовим појмом наратера и у новије време концептом наративне публике Џејмса Фелана и Питера Рабиновича.

Подсетимо, Џералд Принс дефинише наратера као оног коме се приповеда, а који је уписан у текст. Типолошки, наратер показује висок степен варијабилности, у распону од маске читаоца и апелативних фигура (према терминологији Жана Русеа, спољашњи наратер ${ }^{2}$ ), до ликова-наратера (према Русеу, унутрашњи наратер).

Џејмс Фелан и Питер Рабинович наративну публику (за разлику од реалне и идеалне ауторске публике), одређују као публику која „егзистира у свету приче"3 и која ликове и догађаје доживљава као стварне унутар тог света. Иако је реч о релативно новом теоријском моделу, премисе на којима је он изграђен датирају из 70-их година прошлог века, када се под утицајем теорије могућих светова фикцији почиње приписивати важнија улога у креацији секундарних светова.

У улози наративне публике налази се сваки имерзивни читалац, који је, захваљујући наративним компетенцијама емпатије когнитивно и афективно присутан у свету приче коју перципира, без обзира на тип чулне медијације. ${ }^{4}$ Полазећи од метафоре Ричарда Герига о читању као саучествовању, Ма-

\footnotetext{
${ }^{1}$ Изерове анализе се углавном фокусирају на прозне жанрове.

${ }^{2}$ В. о врстама спољашњег наратера у: Милосављевић Милић 2007: 21.

${ }^{3}$ Скрећемо пажњу на промену која се тиче генезе рецептивних инстанци; структуралистички одређени „текст”, замењен је сада когнитивистичким простором „света приче”.

${ }^{4}$ Недавна експанзија когнитивистички усмерених приступа књижевном тексту реактуелизовала је значај урањања као имагинативног насељавања фикционалних светова, те емпатије, као афективног пратиоца овог транссветовног путовања.
} 
ри-Лор Рајан кључним предусловом имерзивног читања сматра процес менталног премештања (2001: 103), будући да управо он омогућава доживљај фикционалних светова као актуелних или стварних. Инстанце читаоца и ликова у концепту наративне публике су онтолошки реверзибилне: стварни читалац постаје фикционално JA, фигура текста, а књижевни лик или текстуална инстанца постаје особа, биће из света приче. ${ }^{5}$

У следећој табели сумирамо основна својства и функције за три наведена рецептивна модела којима ћемо даље у раду посветити више пажње. ${ }^{6}$

\begin{tabular}{|c|c|c|c|c|}
\hline В. Изер & $\begin{array}{l}\text { имплициит- } \\
\text { ни читалац }\end{array}$ & $\begin{array}{l}\text { стратегија тек- } \\
\text { ста, публика } \\
\text { имплицитног } \\
\text { аутора }\end{array}$ & $\begin{array}{l}\text { интеракција и } \\
\text { контрола чи- } \\
\text { тања, } \\
\text { естетска актуе- } \\
\text { лизација }\end{array}$ & $\begin{array}{l}\text { интегратив- } \\
\text { ни чинилац } \\
\text { (метонимијска } \\
\text { фигура) } \\
\text { зависи од } \\
\text { текста - један } \\
\text { имплицитни } \\
\text { читалац }\end{array}$ \\
\hline Џ. Принс & наратер & $\begin{array}{l}\text { ТИ - текста, } \\
\text { приповедачева } \\
\text { публика }\end{array}$ & $\begin{array}{l}\text { реторичко усме- } \\
\text { равање }\end{array}$ & $\begin{array}{l}\text { више врста: } \\
\text { унутрашњи и } \\
\text { спољашњи }\end{array}$ \\
\hline $\begin{array}{l}\text { П. Фелан / } \\
\text { Џ. Рабино- } \\
\text { вич }\end{array}$ & $\begin{array}{l}\text { наративна } \\
\text { публика }\end{array}$ & $\begin{array}{l}\text { имагинарни } \\
\text { становник све- } \\
\text { та дела; нара- } \\
\text { тивна публика } \\
\text { која верује } \\
\text { у стварност } \\
\text { представљеног } \\
\text { света }\end{array}$ & $\begin{array}{l}\text { услов читљи- } \\
\text { вости } \\
\text { критеријум } \\
\text { урањања; од } \\
\text { емпатије до } \\
\text { идентификације }\end{array}$ & $\begin{array}{l}\text { зависност од } \\
\text { света приче }\end{array}$ \\
\hline
\end{tabular}

Рецептивне инстанце у овој трипартитној типологији указују на разлике у концепцији читаоца и у његовој улози на различитим нивоима пријема. Као такве, оне иду у прилог методолошком плурализму, тако да се у анализи књижевног/фикционалног текста могу задржати сва теоријска три аспекта рецепције. Додајмо, притом, да су поменути аутори своје претпоставке базирали на такозваној озбиљној књижевности и интерпретативним компетенцијама „одраслог”, просечног читаоца задржавајући се на синхроном пресеку текстуалних конвенција или жанровској диференцијацији фигуре читаоца, не узимајући у обзир емпиријске аспекте рецепције па ни критеријум узраста, односно, експлицитно циљане публике за коју се пише, као што је то случај са књижевношћу за децу.

\footnotetext{
${ }^{5}$ Оно што Винсен Жув назива „ефекат живота” (1999: 232).

${ }^{6}$ Исцрпан преглед теорија читања и типологија читалаца в. у: М. Бојанић Ћирковић, 2018.
} 


\section{Читалац у књижевности за децу}

С обзиром на то да се жанровска differencia specifica ове врсте књижевности налази у реципијенту, ${ }^{7}$ односно, да се књижевност за децу одређује као онај скуп (најчешће фикционалних) текстова који су интенционално намењени детету као примарном/повлашћеном читаоцу, свако њено тумачење неизоставно укључује ову фигуру. И управо се у томе крије и опасност поједностављивања или погрешног читања овог жанра. Јер, ко је, заправо, читалац у књижевности за децу?

Утицај који су студије културе у последњих неколико деценија извршиле на интерпретативне стратегије у домену науке о књижевности у првом реду се тиче улоге дискуривних пракси (пре свега, идеолошких) у конструкцији значења дела. Са ових позиција дошло је до радикалног превредновања статуса који књижевност за децу има у контексту дијахронијске поетике. Њена увек пратећа, дидактичка компонента, само је олакшала напад на слаба места како се до тада чинило, стабилног жанра. Тако, Карин Лесник-Оберстајн, прихватајући од Жаклин Роуз тезу о конструктивној природи концепта „дете” којом је обојен дискурс критичара, истиче да схватање књижевности за децу као литературе која је адекватна за децу импликује да се ни појам деца ни појам литература у таквом контексту не могу нити изоловати нити задржати своја првобитна независна значења.

[...] књижевност за децу тумачена као „књиге које су добре за децу” сугерише да су појмови који чине њене саставне елементе - деца и књижевност - нераскидиви [...] реч деца у изразу књижевност за децу означава ускоспецифичне замисли о деци, ничим битно везане са осталим концептима „деце” (као што су они присутни у психологији, социологији, историји, уметности, или књижевности) [...] а реч књижевност у склопу књижевности за децу је посебна замисао о књижевности, не строго везана за било коју другу књижевност (Лесник-Оберстајн 2013: 28).

Са ових теоријских позиција проистиче закључак да сваки разговор о одређењу књижевности за децу садржи претпоставку о постојању детета-читаоца као неког целовитог, конзистентног, објективног ентитета што сведочи о очитој повезаности тумачења књижевности за децу са конструкцијом овог појма, као и појма детињство. На додатни парадокс који произилази из овако теоријски зачараног круга поменута ауторка скреће пажњу и ставом да се „Књижевност за децу дефинише као оно што и на плану садржине и на плану форме садржи „потребе деце” па се тако о стварању, издавању, куповини и продаји ових дела међу одраслима говори као да је само „дете” присутно унутар књиге (Лесник-Оберстајн 2013: 28).

Схватање деце-читалаца и књижевности за децу као нечега истоветног, тврди Лесник Оберстајн, води до изненађујућег али прилично распростање-

\footnotetext{
${ }^{7}$ Уколико прихватимо Бахтиново одређење жанра као самог услова читљивости текста, онда би реципијент или аспект пријема као конвенционална фигура читаоца био имплицитно садржан у сваком тексту. У историјској поетици декларативно означавање или чак именовање читаоца за кога се пише налазимо од најранијих дана, а један од конвенционалних начина апелације је онај у паратексту (посвети).
} 
ног методолошког анахронизма, имплицитно садржаног у приступу овим књижевним текстовима као да су их написала сама деца која изражавају своје потребе, осећања и искуства.

Сматрамо да ови теоријски увиди помажу, не само контекстуализацији књижевности за децу унутар историјскопоетичких мена, већ и бољем, ако не и прецизнијем тумачењу фигуре читаоца/читалаца као њене генеричке ознаке. Књижевнотеоријске типологије, посебно оне које се тичу рецептивних инстанци, могу притом имати и релевантан хеуристички потенцијал. Тако се уместо једног и јединственог читаоца (сувише рестриктивног и за реално дете читаоца и за његове текстуалне маске), - у тексту истовремено открива више читалачких, не нужно усаглашених, често и амбивалентних стратегија. Овде ћемо посебно указати на садејство поменуте три категорије: имплицитног читаоца, наратера и наративне публике.

\section{Наратер}

Пођимо од наратера као од читалачке улоге коју је у тексту најлакше препознати и именовати. Интерактивност, као иманентно својство поетике књижевности за децу своју експлицитну манифестацију има у дијалошкој структури текста. Најчешћи саговорник је тада дете, било као унутрашњи наратер, када су у песми/причи фигура читаоца и лик обједињени, било као спољашњи наратер, који је метонимијска замена замишљеног читаоца.

Пример бр. 1 (унутрашњи наратер):

Деда је твој неко,

Што живи тамо далеко.

Што држи твоју слику

У срцу и у новчанику (Милован Витезовић, „Деда”, нав. према: Ценић 2016: 40).

Пример бр. 2 (спољашњи наратер):

Шумски извор - вода питка.

Лепотица - буква витка.

Пурпур сунца јутро зари.

На пропланку купинари.

Видиш децу, чујеш вику.

Поправљају крвну слику! (Томислав Ђокић, „Шумски акварел”, нав. према: Ценић 2016: 105).

C обзиром на то да се степен поклапања реалне публике и наратера смањује са порастом фикционализације наратера (Милосављевић Милић 2007: 21), очекивало би се да је лик детета-читаоца мање саображен са наратером из првог примера него са спољашњим наратером у другом примеру. Утолико пре, што, као у првом примеру лирски субјекат исказа није на истом дијегетичком нивоу са примаоцем исказа. Уобичајено тумачење, међутим, оповргава ову прилично стабилну хипотезу; тако се иначе ликови апострофираног детета - јунака песама тумаче на поједностављен начин, као да 
представљају било које конкретно дете-читаоца (са мање више непроменљивим психофизичким својствима), што је индикативно управо за овде критичком суду изложен есенцијалистички приступ концепту детињства. Стихови из првог примера указују и на реторички аспект читања: наиме, дијалошка, ТИ-форма исказивања (иначе због своје сугестивности фреквентна у књижевности за децу), носи снажан емпатијски потенцијал за урањање у фикционални свет. За разлику од читаве галерије ликова деце у улози унутрашњег наратера, спољашњи наратер (који није лик и не припада свету фикције), мање је конкретизован и мање рестриктиван, често сведен на функцију рецептивне диспозиције пријемчиве различитим типовима реалних читалаца.

\section{Имплицитни читалац}

За разлику од наратера, који у начелу чвршће приања уз конвенције жан$\mathrm{pa},{ }^{8}$ имплицитни читалац је далеко сложенија стратегија читања, јер осим (интер)текстуалних (генеричких конвенција), укључује и бројне вантекстовне параметре, у првом реду когнитивне оквире интерпретације.

Имплицитни читалац је у књижевности за децу одувек имао амбивалентан статус. Из ове рецептивне позиције значење текста је у најмању руку удвостручено - текст се обраћа на једној равни детету, док се на другој равни уочава својеврсни метатекстуални гест усмерен ка реципијенту на дистанци, који чита иза маске детета. Говорећи о феномену подељене или дуплиране публике унутар једног текста Брајан Ричардсон управо у књижевности за децу види најочитији пример постојања двоструког имплицитног читаоца. Шта доноси оваква амбивалентна стратегија читања и зашто је управо имплицитни читалац, како истиче Мајкл Бентон, једна од најпроблематичнијих и најмање истражених фигура читања у књижевности за децу?

Настао као аналогна допуна термину имплицитни аутор (Бут 1966), Изеров термин спецификује, као што је већ поменуто, правац контроле значења којој се реални читалац мора повиновати. Интерпретативни одговор реалног читаоца на текст у том смислу може бити у неком степену усклађен са имплицитним читаоцем, што води ваљаном тумачењу, или може одступати од текстом задатог модела, што за резултат има неадекватна или погрешна читања.

Дуалитет имплицитног читаоца у књижевности за децу најлакше се уочава у текстовима у којима је лирски субјекат истовремено и лирско ЈА, па отуд има статус јунака у фикционалном свету. Као пример навешћемо још једну песму М. Витезовића.

\footnotetext{
${ }^{8}$ Нпр. женска публика епистоларних романа, девојке и младићи у дидактичкој сентименталној прози, путник као слушалац оквирне приче, итд.
} 


\title{
Пример бр. 3
}

\author{
Када завршим школу, \\ Ja xoћy \\ Бити истраживач на Северном полу. \\ Ако си ми прави дед, \\ Ти ћеш ми, као што је ред, \\ Куповати сладолед \\ Да бих се привикао на хладноћу („Припрема”, нав. према: Ценић 2016: 40).
}

У цитираном тексту (унутрашњи) наратер је деда, а имплицитни читалац на првом нивоу је дете чији је лик компатибилан са лирским субјектом, дечаком. На другом нивоу саображени су имплицитни аутор и инстанца одраслог читаоца који, будући да хипостазира и конвенцију првог читања, текст тумачи као да је двоструко позициониран.

Треба рећи да ова рецептивна амбиваленција није привилегија само књижевности за децу'; сличну стратегију уочавамо и у текстовима са непоузданим приповедачем па се у оба случаја може говорити о феномену који је Дејвид Херман назвао „дуплом деиксом”. ${ }^{10}$ Природа разлике између оваквих имплицитних читалаца индикативна је за хијерархијски однос у коме се они налазе; близина имплицитном аутору открива нам идентитет повлашћеног имплицитног читаоца - оног који зна више ${ }^{11}$ и чији чин читања, с једне стране тежи да се утисне у оно прочитано детета (у процесу институционалних или различитим дискурзивним средствима наметнутих когнитивних оквирних метаконцепата), док са друге стране настоји да очува привид поларитета као јемства на којем почива интенционалност књижевности за децу. Њену кључну рецептивну инстанцу, заправо, обележава фино прикривени myse en abyme ефекат: имплицитни читалац-дете само је конструкција имплицитног читаоца на вишем хијерархијском нивоу, који је конструкција текстуалних и историјскопоетичких конвенција.

Увид у овако сложену констелацију читалачких стратегија може бити полазна интерпретативна претпоставка приликом својеврсног синхроног, паралелног читања текста, или код тумачења дела књижевности за децу која припадају традицији. Илустративан је пример песме Рајка Петрова Нога „Ја се онда нарогушим” у којој је упадљива мултипликација и хијерархијски однос имплицитних читалаца.

Све играчке и све справе које за нас децу праве, поломићу из забаве.

\footnotetext{
${ }^{9}$ Налазимо је, између осталог, и код цензурисаних текстова.

${ }^{10}$ Б. Ричардсон имплицитне читаоце једног текста типолошки сагледава у спектру од 1) једног диференцираног имплицитног читаоца, преко 2) дуалног, са јасно одељеним примарним и секундарним типом (ту спада читалац и поновни читалац за текстове који се морају два пута читати), 3) нехијерархизованих дуплих или тродуплих, 4) мултипликованих и хипертекстуалних читалаца, и, најзад, до 5) отворених избора читалачких стратегија (2007: 270).

${ }^{11}$ Према Б. Ричардсону, реч је о хијерархији епистемолошке природе када један читалац зна шта онај други перципира (2007: 263).
} 


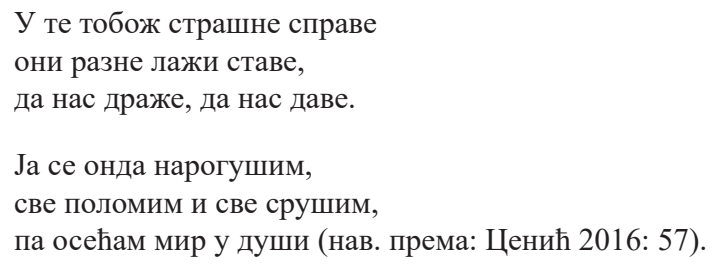

Са друге стране, онај познати феномен нечитљиве традиције који се у књижевности за децу манифестује појавом нискокомуникативних (,застарелих") текстова, делом се може објаснити управо променом оквирних метаконцепата као интерпретативних водича који се више не усаглашавају са инстанцом имплицитног читаоца-детета. У том случају говоримо о феномену заборављеног читаоца. Такође, жанровска предодређеност имплицитног читаоца која је, као што смо поменули, у сложеној интеракцији са доминантним дискурзивним праксама, указује на његово слепо, инертно прихватање у случају познатих генеричких образаца, не уклањајући при том сасвим и проблем имплицитног значења којим је бременит Изеров концепт. Као пример инертног (имплицитног) читаоца поменимо општераспрострањен модел тумачења Антићеве „Шашаве песме” у жанровском контексту љубавне песме и хетеросексуалне љубави (иако у самој песми нема индикативних лингвистичких сигнала за родну диференцијацију) $)^{12}$.

\section{Наративна публика}

Сложеност фигуре читаоца у књижевности за децу још је очигледнија када се у разматрање укључи и концепт наративне публике.

У позицији наративне публике налази се, дакле, сваки читалац који постаје имагинарни саучесник у збивањима/доживљајима фикционалних јунака. При том није реч о арбитрарној улози, већ о услову читљивости. У основи интерактивна, категорија наративне публике представља место сусрета различитих читалаца, а како, према Жан-Мариу Шеферу, „фикционална компетенција није културна конвенција" (Шефер 239), може се говорити о скали имерзивног потенцијала текста, али и читаоца. Према Ж-М. Шеферу, „дете улази у свет фикције кроз игру и сањарење” (2001: 239) тако да ове делатности чине срж његове фикционалне компетенције. Међутим, иако је „миметичко стапање у срцу фикционалног механизма” (Шефер 2001: 181), реч је о „подвојеном менталном стању”, које „искључује свако стање илузије

\footnotetext{
12 У свим српским читанкама за пети разред лирском субјекту ове песме приписује се родна позиција девојчице, иако у тексту нема индикативних лингвистичких сигнала (јавља се само неутрално, 3. л. ј.). Увек остаје отворено питање да ли интерпретативни примат (контролу читања) треба приписати жанровским конвенцијама или идеолошкој конструкцији значења/ лика.
} 
на нивоу свести и убеђења" (Шефер 2001: 194), колико год да је емоционални одговор јак или дуготрајан. ${ }^{13}$

Винсен Жув уводи појам „лисант” под којим подразумева „читаоца у замци референцијалне илузије”, који, док чита, „живи у свету фикције”. Заснивајући своју теорију читања на основама психоанализе и француској традицији поетике рецепције (Пикар, Барт), овај теоретичар управо у фигури лисанта (која је аналогна наративној публици), види поново оживљено дете у нама: „Чим отворимо роман, у нама се поново рађа дете. [...] Читање је жудња за детињством” (Жув 1999: 484). Лудички концепт читаоца и веза коју Жув види између читања и сањарења приписују се изворној компетенцији првобитног искуства, па се на овај начин тематски топоси књижевности за децу тумаче у симболичком семантичком кључу. Више од пружања увида у својства наративне публике (или лисанта) у књижевности за децу, ова истраживачка перспектива иде у прилог апострофирању хијерархијски повлашћеног или примарног имплицитног читаоца (фигура одраслог читаоца), који примат даје дубљем и скривеном подтексту текста.

Притом је важно правити разлику између урањања и идентификације, што се у критици књижевности за децу често превиђа. Претпоставку о идентификацији конкретног читоца детета са ликовима савремени теоретичари сматрају изразито негативним концептом јер, не само да затвара идентитете у самопоновљиво сопство, фаворизујући модел ,доброг детета унутар књиге" као пожељног идентификацијског обрасца, већ и противречи могућности емпатичног одговора читаоца у имагинарној игри уживљавања у улоге сасвим другачијих ликова. У том смислу Сузан Кин говори о идентификацији читаоца са јунацима која претходи емпатији, али то је идентификација схваћена у динамичком смислу преноса (аналогно улози наративне публике), а не у статичном смислу простог огледања (поистовећивања).

Већ поменута песма Р. П. Нога „Ја се онда нарогушим” читљива је управо захваљујући емпатији и урањању, али и дистанци у погледу могуће идентификације читаоца-детета са малим јунаком. Концепт наративне публике је интерпретативно релевантан јер непосредније указује на динамичку, стално променљиву природу рецепције. Њиме се може објаснити ниска комуникативност и слаб емпатијски потенцијал (феномен resisting reader) текстова уз традиције у чијим се фикционалним световима савремено дете-читалац осећа као странац. Са друге стране, поменута рецептивна компетенција може помоћи приликом објашњавања „херменеутичке сложености” многих дела књижевности за децу чији се фикционални светови развијају „на више нивоа сложености” који су „прилагођени различитим узрастима” реципијената (Шефер 2001: 249). И док је у дискрепанцији имплицитних читалаца унутар истог текста реч о квалитативном и хијерархијском поретку, у случају наративне публике разлика је у градацији, степеновању и проширивању/продубљивању граница фикционалног света.

${ }^{13}$ В. О томе у: Милосављевић Милић 2016: 11. 


\section{Закључне напомене}

Приступ књижевности за децу из угла теоријске поетике почива на претпоставци да је задатак науке о књижевности да открива читаоце у тексту и из текста, док би о стварним читаоцима било примереније да говоре психолози или антрополози, не зато што критичари и теоретичари књижевности не би могли да тумаче и такве читаоце, већ зато што они за поетичке и језичке конвенције нису од пресудног значаја.

Мултипликацију фигуре читаоца у књижевности за децу покушали смо отуд да овде типолошки представимо преко три различите рецептивне стратегије које су генерисане текстом и различитим текстуалним конвенцијама, у првом реду жанровским. Уколико смо при том предност дали дескриптивној поетици, то никако не искључује значај историјскопоетичког и ширег друштвеног контекста (пре свега, педагошко-дидактичких дела и различитих облика институционалних образовних стратегија), те емпиријских истраживања, као оних аспеката проучавања који би понудили целовитију слику сложене природе овог жанра и његове рецепције.

\section{ЛИТЕРАТУРА}

Бентон 2013: М. Бентон, Читаоци, текстови, контексти: критички приступ улози читаоца, у: П. Хант (ур), Тумачење књижевности за децу (превела Н. Јанковић), Учитељски факултет, Београд, 125-155.

Бојанић Ћирковић 2018: М. Бојанић Ћирковић, Типологија читалаца у романима Милорада Павића у контексту савремених теорија читања, докторска дисертација, Ниш: Филозофски факултет.

Жув 1999: V. Jouve, Složenost lik-efekta (prevela S. Šoštarić), u: C. Milanja (ur), Autor, pripovjedač, lik, zbonik radova, Osijek: Pedagoški fakultet, 479-573.

Изер 1978: W. Iser, The Act of Reading: A Theory of Aesthetic Response, London and Henley: Routledge \& Kegan Paul.

Лесник Оберстајн 2013: К. Лесник Оберстајн, Основе: Шта је књижевност за децу? Шта је детињство? у: П. Хант (ур), Тумачење књижевности за децу (превела Н. Јанковић), Београд: Учитељски факултет, 27-47.

Милосављевић Милић 2007: С. Милосављевић Милић, Типови наратера у српском реалистичком роману у: Српска реалистичка прича, зборник радова, Крагујевац: ФИЛУМ, 21-34.

Милосављевић Милић 2016: С. Милосављевић Милић, Крв је опет крвава - повратак емоцијама у когнитивној наратологији у: Емоције у култури Срба и Бугара, зборник радова, Ниш: Филозофски факултет, 11-19.

Принс 2003: G. Prince, Dictionary of Narratology, Lincoln and London: University of Nebraska Press. 
Рајан 2001: M-L. Ryan, Narrative as Virtual Reality, Immersion and Interactivity in Literature and Electronic Media, Baltimore and London: The Johns Hopkins University Press.

Ричардсон 2007: B. Richardson, Singular Text, Multiple Implied Readers, Style, Narrative and Self-Knowledge, Vol. 41, No. 3, 259-274.

Pyce 1999: Ž. Ruse, Da li je potrebno govoriti o narateru (prevela M. Djukić), u: S. Perović (ur), Kako ukrotiti tekst, Podgorica: Oktoih, 413-425.

Фелан, Рабинович 2012: J. Phelan, P. Rabinowitz, Reception and the Reader, In: D. Herman, J. Phelan, P. J. Rabinowitz, B. Richardson, R. Warhol, Narrative Theory, Core Concepts and Critical Debates, The Ohio State University Press. S. 139-144.

Ценић 2016: В. Ценић (прир), Заувек ђаџи, ияветник учитеља песника за деиу и младе, Крагујевац: Културно просветно друштво „Троречје”.

Шефер 2001: Ž-M. Šefer, Zašto fikcija? (prev. V. Kapor, B. Rakić), Novi Sad: Svetovi.

Snežana Milosavljević Milić

\section{MODES OF READER'S RESPONDING IN THE CONTEMPORARY SERBIAN CHILDREN'S LITERATURE}

\section{Summary}

Starting from the contemporary theories of reading, in this paper we discuss modes of reception in children's literature related to concept of implied reader (W. Iser), narratee (G. Prince), and narrative audience (J. Phelan, P. Rabinowitz). The concept of child as an ideal recipient and as an immanent generic issue of a certain narrative, challenges in implicit way the question of untuned interpretative strategies. Interpretation of receptive competences of complex and ambivalent figure of child as a reader may be helpfull in the process of reading children' literature and its different fictional worlds, dedicated to different ages. At the same time, description of these modes of responding may be starting point for the revision of methodological aspects of children's literature regarding its generic complexity. As for the source texts for analyse we excerpted the poems of contemporary Serbian poets, Milovan Vitezović and Rajko Petrov Nogo. 